\title{
A new spectrum model for the atmospheric crosswind component applicable from mesoscales to microscales
}

\author{
Larsén, Xiaoli; Larsen, Søren; Petersen, Erik; Mikkelsen, Torben
}

Link to article, DOI:

10.5194/egusphere-egu2020-5240

Publication date:

2020

Document Version

Publisher's PDF, also known as Version of record

Link back to DTU Orbit

Citation (APA):

Larsén, X., Larsen, S., Petersen, E., \& Mikkelsen, T. (2020). A new spectrum model for the atmospheric crosswind component applicable from mesoscales to microscales. Abstract from EGU General Assembly 2020. https://doi.org/10.5194/egusphere-egu2020-5240

\section{General rights}

Copyright and moral rights for the publications made accessible in the public portal are retained by the authors and/or other copyright owners and it is a condition of accessing publications that users recognise and abide by the legal requirements associated with these rights.

- Users may download and print one copy of any publication from the public portal for the purpose of private study or research.

- You may not further distribute the material or use it for any profit-making activity or commercial gain

- You may freely distribute the URL identifying the publication in the public portal

If you believe that this document breaches copyright please contact us providing details, and we will remove access to the work immediately and investigate your claim 
EGU2020-5240

https://doi.org/10.5194/egusphere-egu2020-5240

EGU General Assembly 2020

(c) Author(s) 2020. This work is distributed under

the Creative Commons Attribution 4.0 License.

\title{
A new spectrum model for the atmospheric crosswind component applicable from mesoscales to microscales
}

\author{
Xiaoli Larsén, Søren Larsen, Erik Petersen, and Torben Mikkelsen \\ Technical University of Denmark, Wind Energy Department, Roskilde, Denmark (xgal@dtu.dk)
}

A crosswind spectrum model $S_{v}(f)$ is proposed that covers both the meso and the microscale, ranging in frequency $1 / 5$ day $^{-1}$ to the turbulence inertial subrange. The purpose is to improve the calculation of flow meandering effect over areas of the sizes of offshore wind farms and clusters.

The development is based on measurement (from Høvsøre) analysis over this broad frequency range for cases where wind direction does not change much during a day. The model reads:

$$
\begin{aligned}
f S_{\mathrm{v}}(f) & =\text { Boundary-layer model } & & \text { for } f>f_{1}, \\
& =\text { Constant } & & \text { for } f_{2}<f<f_{1}, \\
& =a_{1} f^{-2 / 3}+a_{2} f^{-2} & & \text { for } \mathrm{f}<f_{2}
\end{aligned}
$$

Here, the frequency range $f_{2}$ to $f_{1}$ defines the gap region, and the constant in this subrange is determined by the spectra on both sides of this range; the boundary-layer model used here is either the Kaimal model or the Mikkelsen-Tchen model; $a_{1}$ and $a_{2}$ are climatological coefficients. The credibility of the model is evaluated against with measurements from another wind test site Østerild, with measurements ranging in height from surface layer to a height of $241 \mathrm{~m}$.

The model is used together with a similar model for the longitudinal wind component $u$ to obtain time series $\mathrm{u}(\mathrm{t})$ and $\mathrm{v}(\mathrm{t})$, from which direction statistics are obtained and compared with those from measurements. It was found that the boundary-layer models could only describe stationary time series for wind vectors. The new v-spectral model improves significantly the statistics of wind direction variation over scales that correspond to offshore wind farms and clusters. 